\title{
Non-HLA genes PTPN22, CDK6 and PADI4 are associated with specific autoantibodies in HLA-defined subgroups of rheumatoid arthritis
}

Omri Snir ${ }^{1 \dagger}$, David Gomez-Cabrero ${ }^{2 \dagger}$, Ariana Montes $^{3}$, Eva Perez-Pampin ${ }^{3}$, Juan J Gómez-Reino ${ }^{3}$, Maria Seddighzadeh ${ }^{1}$, Katharina U Klich', Lena Israelsson ${ }^{1}$, Bo Ding ${ }^{4}$, Anca I Catrina ${ }^{1}$, Rikard Holmdahl', Lars Alfredsson ${ }^{4}$, Lars Klareskog ${ }^{1}$, Jesper Tegnér ${ }^{2}$, Antonio Gonzalez ${ }^{3}$, Vivianne Malmström ${ }^{1}$ and Leonid Padyukov ${ }^{*^{*}}$

\begin{abstract}
Introduction: Genetic susceptibility to complex diseases has been intensively studied during the last decade, yet only signals with small effect have been found leaving open the possibility that subgroups within complex traits show stronger association signals. In rheumatoid arthritis (RA), autoantibody production serves as a helpful discriminator in genetic studies and today anti-citrullinated cyclic peptide (anti-CCP) antibody positivity is employed for diagnosis of disease. The HLA-DRB1 locus is known as the most important genetic contributor for the risk of RA, but is not sufficient to drive autoimmunity and additional genetic and environmental factors are involved. Hence, we addressed the association of previously discovered RA loci with disease-specific autoantibody responses in RA patients stratified by HLA-DRB1*04.
\end{abstract}

Methods: We investigated 2178 patients from three RA cohorts from Sweden and Spain for 41 genetic variants and four autoantibodies, including the generic anti-CCP as well as specific responses towards citrullinated peptides from vimentin, alpha-enolase and type II collagen.

Results: Our data demonstrated different genetic associations of autoantibody-positive disease subgroups in relation to the presence of $D R B 11^{*} 04$. Two specific subgroups of autoantibody-positive RA were identified. The SNP in PTPN22 was associated with presence of anti-citrullinated enolase peptide antibodies in carriers of HLA-DRB $1^{*} 04$ (Cochran-Mantel-Haenszel test $P=0.0001, P_{\text {corrected }}<0.05$ ), whereas SNPs in CDK6 and PADI4 were associated with anti-CCP status in $D R B 1^{*} 04$ negative patients (Cochran-Mantel-Haenszel test $P=0.0004, P_{\text {corrected }}<0.05$ for both markers). Additionally we see allelic correlation with autoantibody titers for PTPN22 SNP rs2476601 and anti-citrullinated enolase peptide antibodies in carriers of HLA-DRB1*04 (Mann Whitney test $P=0.02$ ) and between CDK6 SNP rs42041 and anti-CCP in non-carriers of HLA-DRB1*04 (Mann Whitney test $P=0.02$ ).

Conclusion: These data point to alternative pathways for disease development in clinically similar RA subgroups and suggest an approach for study of genetic complexity of disease with strong contribution of HLA.

\footnotetext{
* Correspondence: leonid.padyukov@ki.se

${ }^{\dagger}$ Equal contributors

'Rheumatology Unit, Department of Medicine at Karolinska University Hospital, Karolinska Institute, Solna, CMM L8:O4 Karolinska Hospital, Stockholm SE-171 76, Sweden

Full list of author information is available at the end of the article
} waiver (http://creativecommons.org/publicdomain/zero/1.0/) applies to the data made available in this article, unless otherwise stated. 


\section{Introduction}

The study of complex diseases has revealed complicated patterns of inheritance [1] in which involvement of multiple variants and environmental conditions, as well as gene-gene and gene-environmental interactions, have made the discovery of genetic causes for complex diseases a challenging task. One main methodological caveat is the definition of phenotypes. As clinical features of complex diseases are heterogeneous, one cannot expect simple genetic patterns to explain such complex heterogeneity. By stratifying for more homogeneous disease subgroups/phenotypes one may try to achieve stronger association and better understanding of disease mechanisms $[2,3]$.

Rheumatoid arthritis (RA) is a common complex disease with incidence around 0.5 to $1.0 \%$ in different populations $[4,5]$ and a steadily growing prevalence in aging Western and Eastern societies. Due to implementation of several targeted treatments in combination with immunosuppressive therapy the overall quality of life for RA patients has dramatically improved and many patients may stay in remission for long periods of time [6]. However, current treatments mostly decelerate rather than cure disease, while disease-driving mechanisms remain poorly understood [6,7]. Despite the discovery of multiple genetic associations with RA, variants within the HLA-DRB1 locus, (that is, HLA-DRB1*04 alleles), remain the most significant contributors to the risk of autoantibody-positive RA [8-14].

Antibody responses against citrullinated epitopes of vimentin, fibrinogen, type-II collagen, alpha-enolase represent specific features of RA $[11,12,15,16]$. Patients may display antibodies to one or several of these modified self-proteins. Most of these autoantibody specificities are confined within, and could thus be recognized on testing as anti-citrullinated cyclic peptide (CCP) antibodies $[11,12]$, which is a generic test recognizing most anticitrulinated peptide antibody (ACPAs). A strong association between the shared epitope (SE) HLA-DRB1 alleles, specifically for SE $H L A-D R B 1 * 04$ alleles, and development of both anti-CCP and anti-citrullinated alpha-enolase peptide-1 (CEP-1) antibodies has been reported [17]. Subsets of RA defined by other combinations of antibodies to citrullinated autoantigens have been shown to display very different degrees of association with the common $H L A-D R B 1$ risk alleles that constitute the group of shared epitope alleles $[18,19]$. These different profiles of ACPAs may reflect distinct biological and immunological courses that are determined by genetic niches of susceptibility. Although it is clinically challenging to differentiate these subgroups due to rather similar symptoms, it is essential to dissect these in view of diagnosis and treatment, and ultimately for the understanding of disease mechanisms and possible prevention.
To find additional links between genetics and serology of RA, which will allow for studies of the relationship between genotypes and phenotypes, we employed a large population-based study from Sweden, the Epidemiological Investigation of Rheumatoid Arthritis (EIRA) with incident cases of RA and two smaller cohorts of cases with well-established/chronic RA. We also considered known relative stability of anti-CCP levels through the RA development [20,21]. Our hypothesis is that a polymorphism outside the HLA-DRB1 locus may contribute and shape the development of certain serological subtypes of RA, which are otherwise clinically indistinguishable. We found that contribution of different non-HLA single nucleotide polymorphisms (SNPs) associated with RA in the development of distinct ACPAs does not overlap, and may define distinct subgroups of disease with an SE-positive or an SE-negative background.

\section{Methods}

\section{Patients and healthy subjects}

DNA and serum samples were collected from three independent cohorts from Sweden and Spain (Additional file 1: Table S13); all experiments were performed in accordance with the Declaration of Helsinki and were approved by Stockholm Ethical Review board or Comite Etico de Investigacion Clinica de Galicia and all subjects gave informed consent. Serum and DNA samples were stored at $-80^{\circ} \mathrm{C}$ until use. This was a case-case study to test the hypothesis of the contribution of different genetic factors in the development of serologically determined subgroups of RA.

The cohorts included were: 1) For initial study we analyzed a cohort of 1,362 patients with incident RA (cohort 1) from a population-based case-control study (EIRA) $[9,22]$. The details of the EIRA study have been described previously [22]. Briefly, a case was defined as a person in the study base who received a new diagnosis of RA from a rheumatologist (within 1 year after the onset of symptoms in $85 \%$ of the cases) and fulfilled the American College of Rheumatology 1987 criteria for the classification of RA [23]. Cases were recruited from all public and a majority of private rheumatology units in the study area; 2) cohort 2 comprised 379 patients with established RA, who all fulfilled the American College of Rheumatology criteria [23] and were attending the Rheumatology Clinic at the Karolinska University Hospital, Stockholm, Sweden; 3) cohort 3 comprised 437 patients with established RA classified according to the 1987 American College of Rheumatology criteria and of Spanish ancestry; DNA and serum samples from these patients were obtained from a single hospital. Their clinical characteristics have been already described in full [24]. 


\section{Serologic measurement}

\section{Detection of IgG anti-CCP antibodies}

ELISA Anti-CCP2 test (Immunoscan RA, Mark 2, EuroDiagnostica, Malmö, Sweden) was used to determine the levels of anti-CCP IgG antibodies. Quantification of the results and use of a cut-off value of $25 \mathrm{U} / \mathrm{ml}$ were according to the manufacturer's instructions.

\section{Detection of IgG antibodies against citrullinated alpha-enolase peptide-1 (CEP-1, citrullinated type-Il collagen (citC1 $\left.{ }^{\prime \prime \prime}\right)$ and citrullinated vimentin (cit-vim) \\ ELISA for detection of IgG antibodies against CEP-1, citC $1^{\mathrm{III}}$ and cit-Vim was preformed as previously de- scribed $[12,19,24]$.}

\section{Genotyping}

\section{HLA-DR genotyping}

DNA was extracted from ethylenediaminetetraacetic acid (EDTA)-treated blood by the salting-out method [25]. Genotyping for $H L A-D R B 1$ allotypes was conducted using the sequence-specific primer-PCR method (DR lowresolution kit; Olerup SSP, Saltsjöbaden, Sweden) as previously described [26]. DRB1*04- and DRB1*01-positive patients were further subtyped by Olerup SSP DRB1*04 (Olerup SSP) subtyping kits, respectively $[27,28]$. In replication cohort 3, HLA-DBR1 alleles were genotyped by a sequencing-based typing method using the AlleleSEQR HLA-DRB1 Typing kit (Abbott Diagnostics, Abbott Park, Germany), which includes bidirectional sequencing of the second exon of DRB1. Ambiguous samples were additionally sequenced with group-specific primers (AlleleSEQR HLADRB1 GSSP, Abbott Diagnostics, Abbott Park, Germany).

\section{Genotyping for RA-predisposing allelic variants}

The 41 SNPs in the first phase of this study were selected from previous studies of genetic risk factors for RA; references for each SNP are presented in Additional file 1: Table S14. These 41 SNPs were studied in the two first cohorts of patients. Genotypes corresponding to the EIRA cohort were retrieved from a genome-wide association study (GWAS) (26 SNPs) [29], from dense mapping of the HLA region (4 SNPs) [30] or from additional genotyping (11 SNPs) that was performed by TaqMan allelic discrimination assay (Applied Biosystems, Foster City, CA, USA). Genotyping of cohort-2 was performed using a 64-OpenArray platform (Applied Biosystems) with the chip-based TaqMan genotyping technology. Genotyping was performed according to manufacturer's instructions, and genotype calls were made using AutoCaller (Applied Biosystems). All SNPs that were analyzed in this study are listed in Additional file 1: Table S14.

With the results of the two first cohorts we selected 12 SNPs for further analysis. The criteria of selection were either a $P$-value $<0.01$ for association of the SNP with a specific subgroup of autoantibody-positive patients in any of the two cohorts, or to show the same direction of association and a $P$-value $<0.2$ in the two cohorts. Genotyping for the 12 selected SNPs in cohort 3 (Spanish patients) was performed by PCR amplification followed by single-base extension with the SNaPshot Multiplex Kit (Applied Biosystems). Details of the protocol are available by the authors upon request. SNP rs2476601 was genotyped with a Taqman SNP genotyping assay (Applied Biosystems, Carlsbad, CA, USA).

\section{Statistical analyses}

We performed analyses either for the whole patient cohort, or for separate $H L A-D R B 1$ *04-positive patients and $H L A-D R B 1 * 04$-negative patients and further calculated the odds ratios (OR) and 95\% CI for the association with anti-CCP and for three ACPA specificities. A dominant genetic model or carrier model that assess the effect of the presence of the risk allele, irrespective of the presence of one or two copies, was used for all analyses to avoid too few counts of some patient subgroups. The OR were calculated by median-unbiased estimation and exact CI using the mid- $P$ method [31] with patients without the specific type of antibody as the reference group.

The three cohorts were jointly analyzed (citC1 ${ }^{\mathrm{III}}$ data were only available for two cohorts) using the CochranMantel-Haenszel (CMH) test. An adjusted P-value of 0.05 after Bonferroni correction for multiple testing was considered statistically significant in the meta-analysis. Homogeneity between cohorts was tested by Tarone's test. As we detected no significant heterogeneity between cohorts a $\mathrm{CMH}$ fixed-effect model was fitted using the restricted maximum-likelihood estimator. The metafor $\mathrm{R}$ package was used for these analyses [32]. Antibody levels and disease activity score in 28 joints (DAS28) were compared by the Mann-Whitney test.

\section{Results}

We determined the associations between genotypes and phenotypes by performing a three-step analysis that is represented in the analytical workflow chart in Figure 1. At the first step, by analysis of cohort 1 and replication in cohort 2, we selected 12 SNPs for further replication. In a second step we validated the results in an independent cohort (cohort 3) and in the third step we estimated OR for RA with certain serologic profiles, based on data from all three cohorts, by meta-analysis. Our main goal was to detect possible associations of non-DRB1 SNPs with autoantibody-defined subgroups in relation to presence/absence of $H L A-D R B 1 * 04$ alleles. However, we also performed analysis for the whole group of patients without this stratification. 


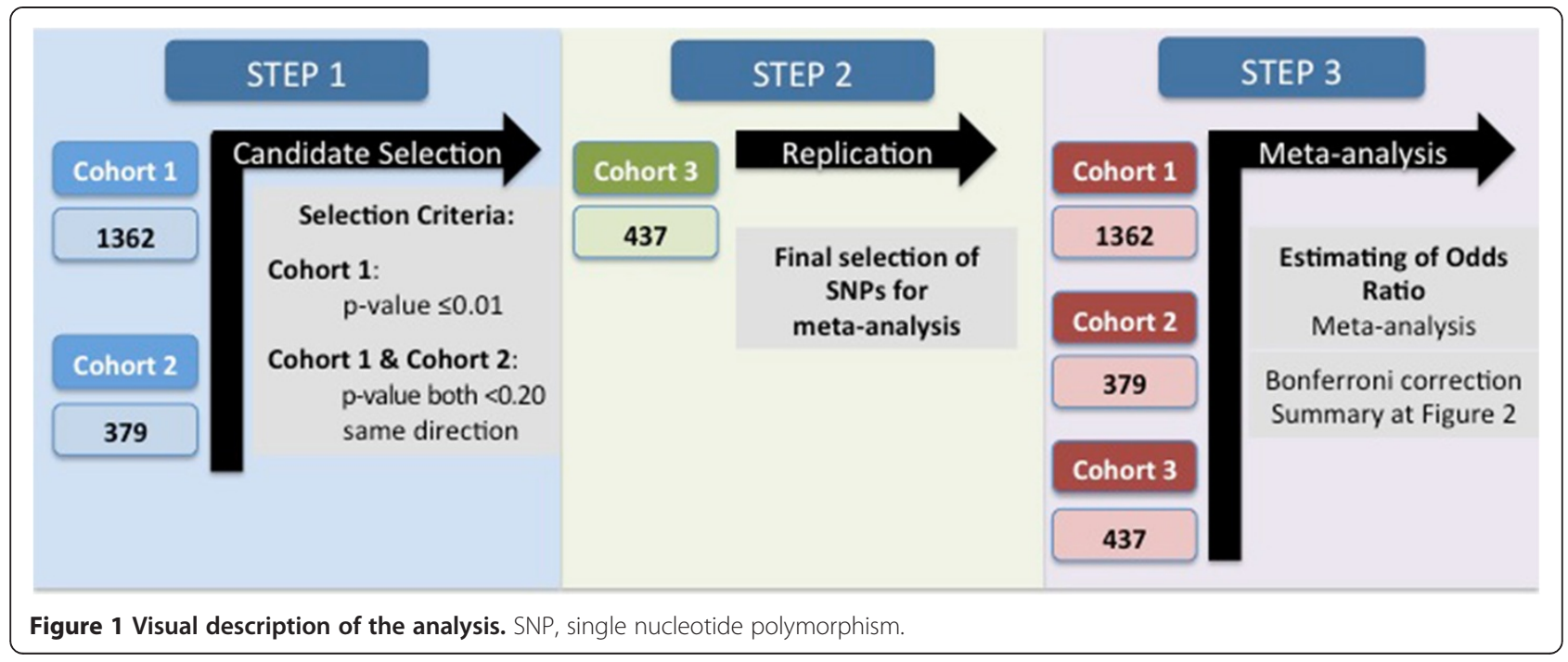

\section{Association study in cohort 1 and cohort 2}

Cohort 1 comprised 1,362 RA patients from the Swedish EIRA study: $70 \%$ of the patients were positive for antiCCP antibodies, whereas defined ACPA fine specificities were less frequent; $50 \%$ of the patients were positive for anti-CEP-1 and $42 \%$ were positive for anti-cit-Vim and for anti-citC1 ${ }^{\mathrm{III}}$ antibodies (Additional file 1: Table S13). We performed a case-case association study to test the hypothesis of different genetic backgrounds between RA subgroups identified by autoantibody specificity. Multiple SNPs were associated in the whole cohort or after stratification by the major SE allele, $H L A-D R B 1 * 04$, but only few passed conservative corrections for multiple testing ( $P \leq 0.0004$, Additional file 1: Tables S1-S4), namely: SNP rs6457617 (HLA-DQB1 gene) for several specificities, for the whole cohort and also after stratification for HLA-DRB1*04, and rs2476601 (PTPN22 gene) for the HLA-DRB1:04-positive RA group with anti-CEP-1 autoantibody.

With the goal to gain better statistical power and to validate the associations identified, we performed analysis in cohort 2, an independent cohort of 379 Swedish RA patients with established disease (Additional file 1: Table S13). Most patients in this cohort were positive for anti-CCP (73\%) and for anti-citVim (58\%). The other two ACPAs were less frequent (46\% for anti-CEP-1 and $38 \%$ for anti-citC1 $\left.1^{\mathrm{III}}\right)$. Again, although multiple SNPs demonstrated a moderate trend towards association, very few passed correction for multiple comparisons (Additional file 1: Tables S5-S8). Therefore, we choose to select the best candidate SNPs from association studies in cohorts 1 and 2 for further validation. Two criteria were used for selection, either a $P$-value $<0.01$ in any of the two cohorts, or a change in the same direction with $P<0.2$ in the two cohorts for the same comparison. This procedure generated a list of 12 SNPs that were used at the next step. Extracted data for association with these SNPs from analyses of cohorts 1 and 2 are presented in Table 1.

\section{Association study in cohort 3}

The 12 SNPs were genotyped in an independent collection of patients of Spanish ancestry, who had established RA $(n=437)$. They showed a similar fraction of antiCCP positivity, but a lower frequency of the ACPAs (Additional file 1: Table S13). The analysis revealed moderate levels of association for SNPs from PTPN22, PADI4, CDK6 and MICA in some disease subgroups (Additional file 1: Tables S9-S11). Importantly, the direction of associations followed the same pattern as in cohorts 1 and 2.

\section{Meta-analysis of the three cohorts}

Following examination for heterogeneity, a fixed-effect meta-analysis was conducted for the association of these SNPs with anti-citrulline immunity in RA using data available from the three cohorts; Table 2 and Figure 2 provide summarized results, which were Bonferronicorrected for the number of tests done. Additional file 1 : Table S12 provides the full disclosure of the analysis.

The results following stratification into carriers of $H L A$ $D R B 1^{*} 04$ and non-carriers of $H L A-D R B 1^{*} 04$ showed associations of the SNP in PTPN22 with antibodies to CEP-1 in the $H L A-D R B 1 * 04$-positive group (adjusted $P$-value 0.007), and of two SNPs, in PADI4 and in CDK6, with anti-CCP response in the $H L A-D R B 1^{*} 04$-negative group (adjusted p-value 0.038 and 0.034 , respectively). In addition, two SNPs showed a trend to association with $P$-value $<0.1$ in the non-carriers of HLA-DRB1*04: CDK6 and $P R K C Q$ with anti-citVim and anti-CEP-1 respectively (Table 2, Additional file 1: Table S12, and Figure 2). These data additionally endorse the association of RA subgroups 
Table 1 Selected associations found in cohorts 1 and 2

\begin{tabular}{|c|c|c|c|c|c|c|c|}
\hline Gene & rs number & Chromosome & Position & $\begin{array}{l}\text { Cohort } 1 \\
P \text {-value }\end{array}$ & $\begin{array}{l}\text { Cohort } 1 \text { odds ratio } \\
(95 \% \mathrm{Cl})\end{array}$ & $\begin{array}{l}\text { Cohort } 2 \\
P \text {-value }\end{array}$ & $\begin{array}{l}\text { Cohort } 2 \text { odds ra } \\
(95 \% \mathrm{Cl})\end{array}$ \\
\hline \multicolumn{8}{|l|}{ Anti-CCP } \\
\hline \multicolumn{8}{|c|}{ Anti-CCP - all patients } \\
\hline PTPN22 & rs2476601 & 1 & 114179091 & 0.119 & $1.235(0.948,1.617)$ & 0.104 & $1.519(0.920,2.569)$ \\
\hline MICA & rs2523451 & 6 & 31477130 & 0.062 & $1.382(0.984,1.938)$ & 0.035 & $1.707(1.039,2.795)$ \\
\hline$H L A-D Q B 1$ & rs6457617 & 6 & 32771829 & $2.22 \times 10^{-16}$ & $4.232(2.998,6.008)$ & 0.131 & $2.028(0.803,4.911)$ \\
\hline CDK6 & rs42041 & 7 & 92084680 & 0.017 & $1.368(1.056,1.777)$ & 0.162 & $1.404(0.874,2.285)$ \\
\hline \multicolumn{8}{|c|}{ Anti-CCP-- HLA-DRB1*04 patients } \\
\hline PTPN22 & rs2476601 & 1 & 114179091 & 0.018 & $1.67(1.090,2.628)$ & 0.19 & $1.751(0.765,4.415)$ \\
\hline \multicolumn{8}{|c|}{ Anti-CCP - Non-HLA-DRB1*04 patients } \\
\hline PAD/4 & rs2240340 & 1 & 17535226 & 0.012 & $1.718(1.128,2.625)$ & 0.15 & $1.627(0.838,3.176)$ \\
\hline CDK6 & rs42041 & 7 & 92084680 & 0.001 & $1.831(1.265,2.660)$ & 0.055 & $1.909(0.987,3.772$ \\
\hline
\end{tabular}

Citrullinated-vimentin

Citrullinated-vimentin - all patients

$\begin{array}{lll}\text { PTPN22 } & \text { rs2476601 } & \mathbf{1} \\ \text { MICA } & \text { rs2523451 } & 6 \\ \text { HLA-DQB1 } & \text { rs6457617 } & \mathbf{6} \\ \text { HLA-DPB1 } & \text { rs2064476 } & 6 \\ \text { TRAF1 } & \text { rs3761847 } & 9\end{array}$

$\begin{array}{lllll}\mathbf{1 1 4 1 7 9 0 9 1} & \mathbf{0 . 0 4 8} & \mathbf{1 . 2 7 2}(\mathbf{1 . 0 0 2}, \mathbf{1 . 6 1 4}) & \mathbf{0 . 0 2 1} & \mathbf{1 . 6 9 1}(\mathbf{1 . 0 8 3}, \mathbf{2 . 6 6 7}) \\ \mathbf{3 1 4 7 7 1 3 0} & \mathbf{0 . 0 0 5} & \mathbf{1 . 5 9 5 ( 1 . 1 5 1 , 2 . 2 2 1 )} & \mathbf{0 . 0 0 9} & \mathbf{1 . 8 1 8}(\mathbf{1 . 1 6 2 , 2 . 8 5 1 )} \\ \mathbf{3 2 7 7 1 1 8 2 9} & \mathbf{2 . 3 6} \times \mathbf{1 0}^{-\mathbf{1 0}} & \mathbf{3 . 4 1 7}(\mathbf{2 . 2 8 5}, \mathbf{5 . 2 6 6}) & \mathbf{0 . 0 0 1} & \mathbf{4 . 9 4 8}(\mathbf{1 . 8 9 0 , 1 5 . 6 5 2 )} \\ 33181300 & 0.19 & 1.636(0.787,3.594) & 0.028 & 3.228(1.132,10.682) \\ 122730060 & 0.088 & 1.254(0.967,1.631) & 0.171 & 1.406(0.863,2.289)\end{array}$

Citrullinated-vimentin - HLA-DRB1*04 patients

\begin{tabular}{|c|c|c|c|c|c|c|c|}
\hline PTPN22 & rs2476601 & 1 & 114179091 & 0.022 & $1.437(1.054,1.967)$ & 0.04 & $1.912(1.029,3.672)$ \\
\hline MICA & rs2523451 & 6 & 31477130 & 0.085 & $1.495(0.945,2.362)$ & 0.133 & $1.639(0.858,3.106)$ \\
\hline \multicolumn{8}{|c|}{ Citrullinated-vimentin - non-HLA-DRB1*04 patients } \\
\hline HLA-DQB1 & rs6457617 & 6 & 32771829 & 0.161 & $1.387(0.880,2.233)$ & 0.042 & $2.814(1.034,9.151)$ \\
\hline \multicolumn{8}{|l|}{ CEP-1 } \\
\hline \multicolumn{8}{|c|}{ CEP-1- all patients } \\
\hline PTPN22 & rs2476601 & 1 & 114179091 & 0.016 & $1.339(1.055,1.702)$ & 0.078 & $1.475(0.957,2.279)$ \\
\hline HLA-DQB1 & rs6457617 & 6 & 32771829 & $5.11 \times 10^{-11}$ & $3.213(2.242,4.676)$ & 0.166 & $1.896(0.772,5.144)$ \\
\hline PRKCQ & rs4750316 & 10 & 6433266 & 0.133 & $1.204(0.945,1.534)$ & 0.004 & $1.86(1.220,2.849)$ \\
\hline HTR2A & rs1328674 & 13 & 46339708 & 0.187 & $1.33(0.871,2.051)$ & 0.115 & $1.924(0.854,4.546)$ \\
\hline \multicolumn{8}{|c|}{ CEP-1 - HLA-DRB $1 * 04$ patients } \\
\hline CIITA & rs6416647 & 16 & 10873098 & 0.011 & $1.525(1.099,2.121)$ & 0.194 & $1.431(0.833,2.468)$ \\
\hline \multicolumn{8}{|c|}{ CEP-1 - non-HLA-DRB1*04 patients } \\
\hline HLA-DQB1 & rs2064476 & 6 & 33181300 & 0.002 & $1.894(1.268,2.865)$ & 0.155 & $3.8(0.656,97.488)$ \\
\hline PRKCQ & rs4750316 & 10 & 6433266 & 0.106 & $1.379(0.934,2.035)$ & 0.003 & $2.919(1.446,5.965)$ \\
\hline \multicolumn{8}{|l|}{ CitC1 ${ }^{\prime \prime \prime}$} \\
\hline \multicolumn{8}{|c|}{ CitC1'II - all patients } \\
\hline MMELI & rs3890745 & 1 & 2543484 & 0.158 & $1.319(0.899,1.959)$ & 0.122 & $1.883(0.850,4.634)$ \\
\hline CDK6 & rs42041 & 7 & 92084680 & 0.166 & $1.181(0.933,1.495)$ & 0.044 & $1.549(1.012,2.372)$ \\
\hline \multicolumn{8}{|c|}{ CitC1 - HLA-DRB $1 * 04$ patients } \\
\hline TNFAIP3 & rs6920220 & 6 & 138048197 & 0.067 & $1.796(0.960,3.504)$ & 0.052 & $3.254(0.991,15.257)$ \\
\hline \multicolumn{8}{|c|}{$\mathrm{CitC}^{\prime \prime \prime \prime}$ - non-HLA-DRB1*04 patients } \\
\hline CDK6 & rs42041 & 7 & 92084680 & 0.038 & $1.502(1.023,2.210)$ & 0.051 & $1.99(0.997,3.988)$ \\
\hline
\end{tabular}

P-values in bold represent the most significant associations with values $<0.05$ for both cohorts. 
Table 2 Association of genetic markers with serological subgroups of rheumatoid arthritis: meta-analysis summary Anti-CPP

$H L A-D R B 1{ }^{*} 04$-positive group

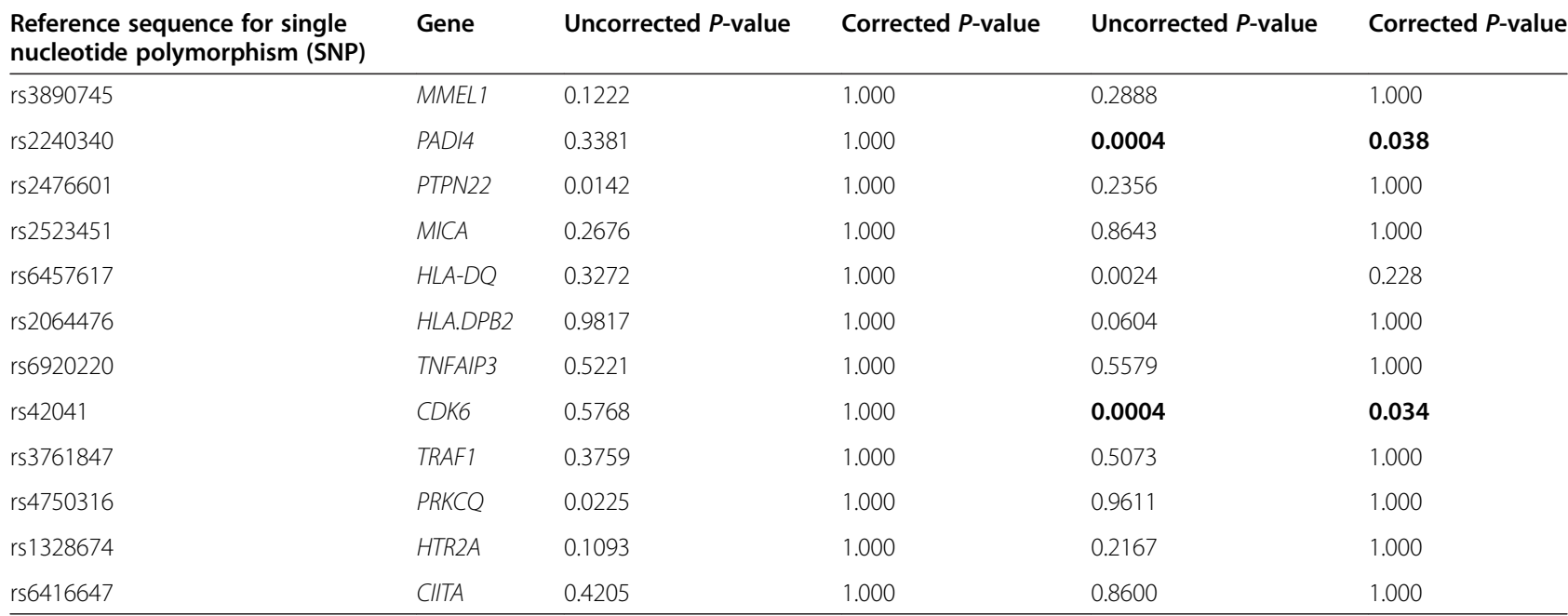

HLA-DRB1*04-positive group

\begin{tabular}{|c|c|c|c|c|c|}
\hline Reference sequence for SNP & Gene & Uncorrected $P$-value & Corrected $P$-value & Uncorrected $P$-value & Corrected $P$-value \\
\hline rs3890745 & MMEL 1 & 0.1174 & 1.000 & 0.8047 & 1.000 \\
\hline rs2240340 & PAD/4 & 0.1918 & 1.000 & 0.2833 & 1.000 \\
\hline rs2476601 & PTPN22 & 0.0111 & 1.000 & 0.9087 & 1.000 \\
\hline rs2523451 & MICA & 0.0394 & 1.000 & 0.0713 & 1.000 \\
\hline rs6457617 & $H L A-D Q$ & 0.6668 & 1.000 & 0.0727 & 1.000 \\
\hline rs2064476 & HLA.DPB2 & 0.0172 & 1.000 & 0.1853 & 1.000 \\
\hline rs6920220 & TNFAIP3 & 0.0601 & 1.000 & 0.9923 & 1.000 \\
\hline rs42041 & CDK6 & 0.8207 & 1.000 & 0.0009 & 0.088 \\
\hline rs3761847 & TRAF1 & 0.0877 & 1.000 & 0.2822 & 1.000 \\
\hline rs4750316 & PRKCQ & 0.8846 & 1.000 & 0.0231 & 1.000 \\
\hline rs1328674 & HTR2A & 0.0557 & 1.000 & 0.3165 & 1.000 \\
\hline rs6416647 & CIITA & 0.1542 & 1.000 & 0.3807 & 1.000 \\
\hline \multicolumn{6}{|l|}{ anti-CEP-1 } \\
\hline & & \multicolumn{2}{|c|}{$H L A-D R B 1$ *04-positive group } & \multicolumn{2}{|c|}{$H L A-D R B 1 * 04$-negative group } \\
\hline Reference sequence for SNP & Gene & Uncorrected $P$-value & Corrected $P$-value & Uncorrected $P$-value & Corrected $P$-value \\
\hline rs3890745 & MMEL 1 & 0.9475 & 1.000 & 0.0240 & 1.000 \\
\hline rs2240340 & PAD/4 & 0.6073 & 1.000 & 0.4651 & 1.000 \\
\hline rs2476601 & PTPN22 & 0.0001 & 0.006 & 0.4364 & 1.000 \\
\hline rs2523451 & MICA & 0.1623 & 1.000 & 0.1834 & 1.000 \\
\hline rs6457617 & $H L A-D Q$ & 0.0558 & 1.000 & 0.0028 & 0.267 \\
\hline rs2064476 & HLA.DPB2 & 0.3083 & 1.000 & 0.6594 & 1.000 \\
\hline rs6920220 & TNFAIP3 & 0.8999 & 1.000 & 0.5037 & 1.000 \\
\hline rs42041 & CDK6 & 0.3235 & 1.000 & 0.0459 & 1.000 \\
\hline rs3761847 & TRAF1 & 0.6790 & 1.000 & 0.2747 & 1.000 \\
\hline rs4750316 & PRKCQ & 0.5904 & 1.000 & 0.0007 & 0.070 \\
\hline rs1328674 & HTR2A & 0.0582 & 1.000 & 0.2357 & 1.000 \\
\hline rs6416647 & CIITA & 0.0089 & 0.852 & 0.8989 & 1.000 \\
\hline
\end{tabular}

$H L A-D R B 1 * 04-$ negative group 
Table 2 Association of genetic markers with serological subgroups of rheumatoid arthritis: meta-analysis summary (Continued)

\begin{tabular}{|c|c|c|c|c|c|}
\hline \multicolumn{6}{|l|}{ anti- CitC1"III } \\
\hline \multirow[b]{2}{*}{ Reference sequence for SNP } & \multirow[b]{2}{*}{ Gene } & \multicolumn{2}{|c|}{$H L A-D R B 1 * 04$-positive group } & \multicolumn{2}{|c|}{$H L A-D R B 1 * 04-$ negative group } \\
\hline & & Uncorrected $P$-value & Corrected $P$-value & Uncorrected $P$-value & Corrected $P$-value \\
\hline rs3890745 & MMEL1 & 0.1310 & 1.000 & 0.2013 & 1.000 \\
\hline rs2240340 & PAD/4 & 0.5328 & 1.000 & 0.1821 & 1.000 \\
\hline rs2476601 & PTPN22 & 0.2301 & 1.000 & 0.3068 & 1.000 \\
\hline rs2523451 & MICA & 0.3840 & 1.000 & 0.9666 & 1.000 \\
\hline rs6457617 & $H L A-D Q$ & 0.4136 & 1.000 & 0.0021 & 0.201 \\
\hline rs2064476 & HLA.DPB2 & 0.9029 & 1.000 & 0.9872 & 1.000 \\
\hline rs6920220 & TNFAIP3 & 0.0148 & 1.000 & 0.6307 & 1.000 \\
\hline rs42041 & CDK6 & 0.4844 & 1.000 & 0.0054 & 0.522 \\
\hline rs3761847 & TRAF1 & 0.8086 & 1.000 & 0.3773 & 1.000 \\
\hline rs4750316 & PRKCQ & 0.5519 & 1.000 & 0.3662 & 1.000 \\
\hline rs1328674 & HTR2A & 0.6374 & 1.000 & 0.3458 & 1.000 \\
\hline rs6416647 & CIITA & 0.2613 & 1.000 & 0.7296 & 1.000 \\
\hline
\end{tabular}

Odds ratios are presented in Figure 2; full details are presented in Additional file 1: Table S12. P-values in bold represent the most significant associations with corrected values $<0.10$.

with the CDK6 polymorphism and suggest $P R K C Q$ as a relevant candidate for follow-up studies.

In the analyses without stratification according to $H L A-D R B 1 * 04$, the SNP assigned to MICA was associated with response to cit-Vim (adjusted $P$-value 0.008 ), the PTPN22 SNP was associated with antibodies to CEP-1 (adjusted $P$-value 0.012 ), and the $H L A-D Q B 1$ SNP was associated with the anti-citCl ${ }^{\mathrm{III}}$ antibodies (adjusted $P=9 \times 10^{-5}$ ) (Additional file 1: Table S12). These findings suggest a relative independence of the association with the MICA SNP from HLA-DRB1*04 as the $\mathrm{OR}$ are very uniform in the two groups of patients stratified by this allele $(\mathrm{OR}=1.4$ in the carriers and in non-carriers). This independence was not present in the association with the PTPN22 SNP that showed a stronger significant association in the carriers of DRB1*04 than in the non-carriers $(\mathrm{OR}=1.7$ and 1.1, respectively).

\section{Analysis of serological and clinical data}

As our data showed that SNPs in PADI4, PTPN22 and $C D K 6$ together with $H L A-D R B 1 * 04$ carrier status were associated with the presence of some autoantibodies, we tested if the genotypes were correlated with the titers of these antibodies. We saw a coherent significant difference for anti-CCP antibody levels between homozygous $\mathrm{CC}$ patients and those carrying the $\mathrm{G}$ allele of rs42041 from $C D K 6$ in cohort 1 and 2 for patients without DRB 1*04 alleles $(P=0.0193$ and 0.0290 for cohorts 1 and 2, Additional file 2: Figure S1a). Similarly, patients having the AA/AG variant of rs2476601 from PTPN22 had higher levels of antibodies towards cit-Vim in cohort 1 and 2 but only in patients with $D R B 1 * 04$ alleles $(P=0.0238$, Additional file 2: Figure S1c).

To compare genetic subgroups defined by certain autoantibody specificity, HLA-DRB1:04 and non-HLA alleles (PTPN22, PADI4 and CDK6), we analyzed data on disease activity at baseline in cohort 1 measured by the DAS28, but no differences were found (data not shown).

\section{Discussion}

In this study we have demonstrated that specificity of autoantibody responses in seropositive RA is regulated not only by $H L A-D R B 1^{*} 04$, but also by at least three additional non-HLA genetic variants: PADI4, PTPN22 and $C D K 6$. Our data suggest that PTPN22 involvement is restricted to $H L A-D R B 1^{*} 04$ carriers, while associations of PADI4 and CDK6 are restricted to the non-carriers, and they also differ in autoantibody specificity. While concordance of $H L A-D R B 1 * 04$ and PTPN22 SNP in anti-CEP-1 positive RA was demonstrated previously in a single cohort $[17,19]$, the involvement of genetic variants of PADI4 and CDK6 in risk of development of RA subgroups only in the absence of $H L A-D R B 1^{*} 04$ is a new finding. We also have observed a difference in the autoantibody titers corresponding with the previous associations, (Additional file 2: Figure S1) while no difference was found in relation to clinical activity of disease at baseline measured by the DAS28.

Genetic and environmental factors are involved in the etiology of complex diseases. In RA, such susceptibility factors have been primarily found for ACPA-positive disease [7,9,33]. Among RA-predisposing genes, the 


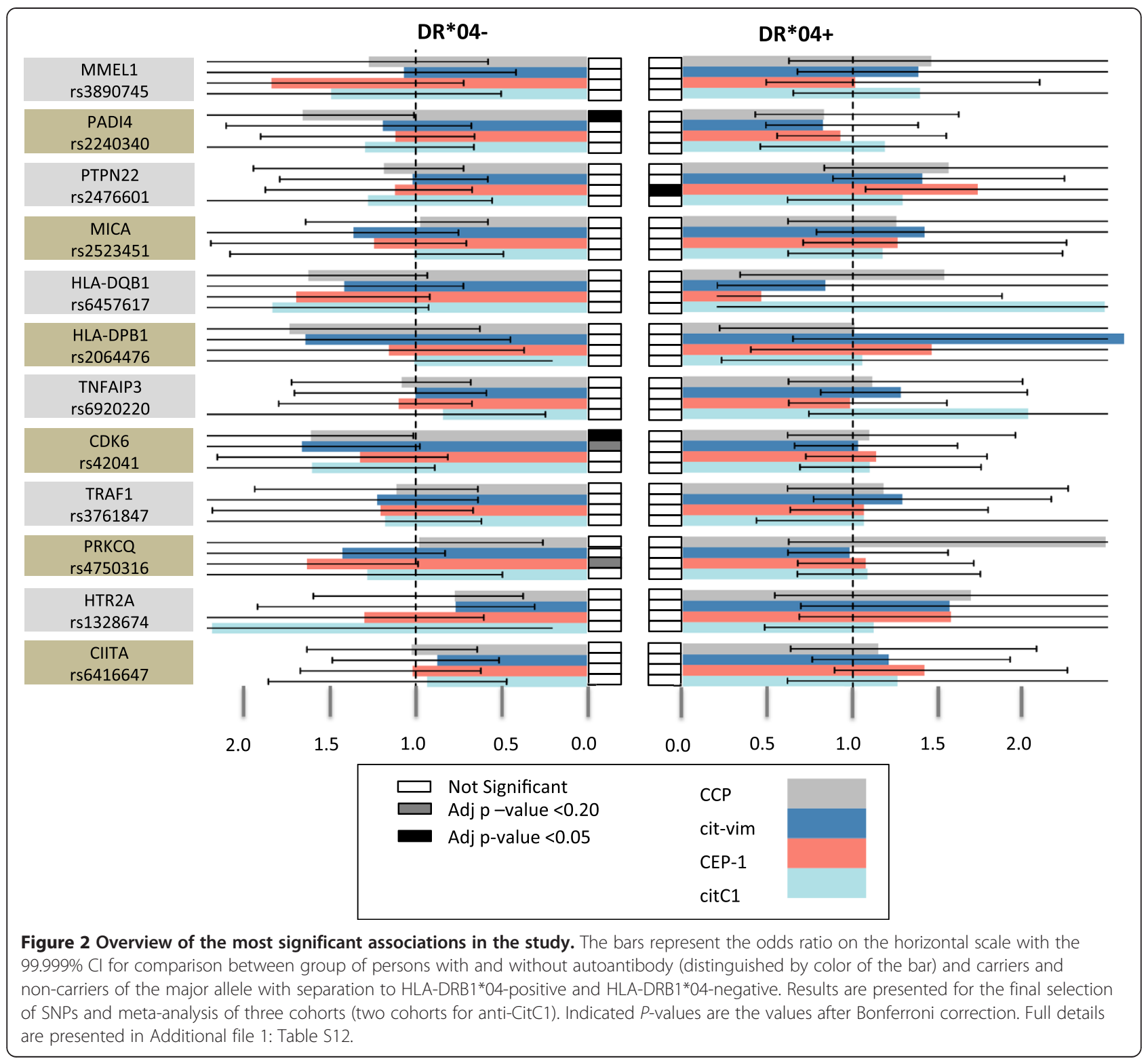

involvement of the $H L A-D R B 1$ polymorphism has been extensively studied, as it was the first identified and it was also the strongest to date $[27,34]$. Association of the shared epitope alleles of HLA-DRB1 with ACPA (antiCCP)-positive RA indicates probable mechanisms for disease development. In this work, we further examined the significance of other, mainly non-HLA variants, for the development of different autoantibodies in a casecase study. We investigated the effects of these genetic variants alone or in combination with $H L A-D R B 1 * 04$, the most frequent $\mathrm{SE}$ alleles in European Caucasians, in three independent RA cohorts. Although the selection of SNPs was based on RA susceptibility studies our results are not related to susceptibility by itself, because no comparison with healthy individuals was done.
Despite the fact that $H L A-D R B 1^{*} 04$ alleles are strongly associated with RA and anti-citrulline immunity, few studies have so far addressed the contribution of these allelic variants to RA development via antigen presentation of citrullinated peptides [35-38]. It is not clear why and how HLA-DRB1"04-positive RA patients develop ACPAs with different specificities towards non-overlapping epitopes. It is therefore possible that the $H L A-D R^{*} 04$ alleles (mainly *04:01) together with additional genes outside this region work collectively to shape ACPA responses in RA. In this study, we found three allelic variants outside $H L A-D R B 1$ that associate with a particular type of autoantibody in RA. These genetic differences may provide a plausible explanation for the phenotypic heterogeneity of RA, for example, differences in the autoantibody profile of RA 
patients. However, the precise functional contribution of these variants to RA development remains to be determined.

The PTPN22 gene (MIM ID*600716) encodes an 807 amino acid lymphoid tyrosine phosphatase of nonreceptor type (LYP). An SNP in this gene was found to be associated with several autoimmune diseases [39]. This SNP is a non-synonymous change of arginine for tryptophan at position 620 of the protein. The biochemical effect and the resulting disease risk of this SNP have been very difficult to study and there is not yet consensus about its functional consequences. It has been suggested that this SNP determines a gain of function of the LYP phosphatase, but there other studies showing a loss of function of LYP when analyzed together with the c-Src tyrosine kinase [40]. Therefore, it is still unclear how the R620W change might contribute to autoimmunity. In addition, most studies of PTPN22 function refer to T cell function either at the level of thymic selection or of mature $\mathrm{T}$ cell activation, but B cells also express LYP and the removal of autoreactive $B$ cells is deficient in subjects bearing the risk allele of PTPN22, making for alternative mechanisms of disease risk [41].

The CDK6 gene (MIM ID* 603368) encodes a 326 amino acid serine/threonine-protein kinase, which is ubiquitously expressed and involved in cell cycle control and differentiation by promoting G1/S transition. A genetic polymorphism at CDK6 was recently found to be associated with RA [42] and with joint destruction during RA [43]. Interestingly, polymorphisms in this gene are also associated with adult height [44] and with white blood cells counts in some populations $[45,46]$.

The PADI4 gene (MIM ID*605347) codes for peptidyl arginine deiminase, type 4 , which mediates citrullination of different proteins, including histones. In histones, citrullination affects methylation and this way PADI4 influences gene expression [47]. PADI4 variants have previously been observed to be associated with RA in the Japanese population [48] and recently in European Caucasians [49]. Although the enzyme is directly involved in citrullination of proteins, until now genetic association has not been restricted to RA patients positive for autoantibodies to citrullinated antigens [50].

There were three loci showing significant association with particular autoantibodies in the analysis nonstratified by $H L A-D R B 1 * 04$. The associations between the anti-citC $1^{\mathrm{III}}$ antibodies and the $H L A-D Q B 1$ SNP and between the anti-citVim antibodies and the SNP in $M I C A$ could reflect linkage disequilibrium with the shared epitope alleles of HLA-DRB1 because these SNPs are in the HLA region. However, we cannot exclude an effect of other variants in this region as has been shown for RA susceptibility [13]. The third association, between anti-CEP-1 antibodies and the PTPN22 SNP and anti-
CEP-1 antibodies, although observed in the non-stratified analysis was not independent of the presence of $H L A$ $D R B 1 * 04$. It was much stronger in the carriers of $H L A$ $D R B 1 * 04$ than in the non-carriers, as already discussed.

What are the possible mechanisms underlying the identified associations and how will our findings affect the understanding of, or the management of RA? It is clear that $H L A-D R B 1^{*} 04$, as well as other SE alleles, do not represent a single determinant for development of autoimmune responses. We previously demonstrated the possibility of gene-gene and gene-environment interactions in the development of RA which suggested that smoking and several non-HLA genes could serve as possible second determinants for a break in tolerance to self antigens and the development of RA. Two of the genes in our study, CDK6 and PTPN22, are directly involved in signaling pathways that are essential for immune cell function. However, due to redundancy of these pathways we cannot point to the specific type of cells that are involved in the development of disease: it could be downstream mechanisms with $\mathrm{T}$ helper cells as primer players, or upstream mechanisms related to antigen presenting cells, B cells, macrophages/monocytes or dendritic cells. As the combination of $H L A-D R B 1 * 04$ and variations from these genes are unlikely to be sufficient for RA development, one would expect a third determinant to be involved in this interaction. Our findings warrant future studies of the development of autoimmune responses in individuals at risk of RA, with certain subphenotypes, based on serological testing. It would guide both understanding of specific mechanisms and probable treatment towards precision medicine in contrast to current treatment based on relatively non-specific immunosuppressive therapy (that is, RA symptoms). Such studies may guide both understanding of specific mechanisms and future development of more specific therapies for patients from these different subsets. One such option that may be discussed based on our current observations in ACPA-negative RA patients is to test the selective cyclin-dependent kinase 4/6 (CDK4/6) inhibitor (Momilactone B) which is currently being investigated for treatment of colon cancer [51].

There are several strengths in our study. First, we performed analysis in three independent cohorts of RA patients. Second, we used cohorts from two different countries, with different frequencies of autoantibodies, and different types of RA. This variability between sample collections is important for generalization of our findings. Third, our final conclusions were based on the Bonferroni correction and this is a very conservative approach when analyzing correlated variables, such as the four autoantibodies in our study.

There are also some weaknesses in the current study: 1) as the phenotypes we have studied involved a combination of traits, they comprised relatively small numbers 
of observations even with several thousands of patients included in the study; 2) inclusion of incident cases (EIRA) and established RA (cohorts 2 and 3) may have decreased the power of our study to discover associations that are specific for a particular disease phase; 3) we did not address the contribution of other SE alleles beyond $D R B 1 \% 04$ in our study due to a relatively low frequency of $H L A-D R B 1 * 01$ and "10 in our cohorts; 4) it also would be beneficial to address the influence of smoking, but we did not have enough statistical power for inclusion of an additional covariate in our analyses.

\section{Conclusions}

Autoimmune diseases display strong association with HLA alleles, but a substantial number of non-HLA variants are also associated at genome-wide level. Specific subphenotype analyses of these associated loci have been rare, and have usually not been stratified by HLA alleles. Our study provides a prototype that could be useful for other studies aiming to disentangle RA complexity. The ongoing replications and extensions of such studies should provide a basis for a molecular re-classification of RA based on genetic and serological features, rather than mainly on clinical data [52]. Specifically, our study confirms the hypothesis that polymorphisms outside the HLA-DRB1 locus contribute to the development of specific serological subphenotypes of RA, which may have different mechanisms of disease development.

\section{Additional files}

Additional file 1: Table S1. Association between anti-citrullinated cyclic peptide (anti-CCP) and single nucleotide polymorphisms (SNPs) in cohort 1. Table S2. Association between anti-Cit-Vimentin and SNP in cohort 1. Table S3. Association between anti-citrullinated alpha-enolase peptide-1 (CEP-1) and SNP in cohort 1. Table S4. Association between anti-CitC1 ${ }^{11 !}$ and SNP in cohort 1. Table S5. Association between anti-CCP and SNP in cohort 2. Table S6. Association between anti-Cit-Vimentin and SNP in cohort 2. Table S7. Association between anti-CEP1 and SNP in cohort 2. Table S8. Association between anti-CitC1 and SNP in cohort 2. Table S9. Association between anti-CCP and SNP in cohort 3. Table S10. Association between anti-Cit-Vimentin and SNP in cohort 3. Table S11. Association between anti-CEP-1 and SNP in cohort 3. Table S12. Complete meta-analysis results. Table S13. Baseline characteristics of three analyzed RA cohorts. Table S14. Genetic variants used in the study.

Additional file 2: Figure S1. Levels of autoantibodies in relation to CDK6, PADI4 and PTPN22 genotypes. Subjects from cohort 1 (upper panel) and cohort 2 (lower panel) were classified negative or positive to HLA-DRB 1*04 and according to their CDK6, PAD/4 or PTPN22 genotypes. Antibody levels against CCP (CDK6, PAD/4) and cit-Vim (PTPN22) were compared between the different genotype groups. Bars indicate the median levels of antibody response. ${ }^{*} \mathrm{P}<0.05$.

\section{Abbreviations}

ACPA: anti-citrullinated peptide antibody; anti-CCP: anti-citrullinated cyclic peptide; CEP-1: citrullinated alpha-enolase peptide-1; citC1'1!: citrullinated type-Il collagen trimer; cit-Vim: citrullinated vimentin; $\mathrm{CMH}$ test: Cochran-Mantel-Haenszel test; DAS28: disease activity score based on 28 joints; EIRA: epidemiological investigation of rheumatoid arthritis; ELISA: enzyme-linked immunosorbent assay; GWAS: genome-wide association study; HLA: human leucocyte antigen (locus); LYP: Iymphocyte phosphatase; OR: odds ratio; PCR: polymerase chain reaction; RA: rheumatoid arthritis; SE: shared epitope; SNP: single nucleotide polymorphism. Gene names are not listed and follow current genetic nomenclature.

\section{Competing interests}

The authors declare that they have no competing interests.

\section{Authors' contributions}

OS, DGC, AG, VM and LP made substantial contributions to conception and design, acquisition of data, analysis and interpretation of data; AM, EPP, JJGR, MS, KUK, LI and AIC made substantial contributions in acquisition of data; BD made substantial contributions to analysis and interpretation of data; $R H, L A$, LK and JT made substantial contributions to conception and design of the study; OS, DGC, AG, VM and LP have been involved in drafting the manuscript and revising it critically for important intellectual content; AM, EPP, JJGR, MS, KUK, LI, AIC, RH, LA, LK and JT have been involved in revising the manuscript critically for important intellectual content. All authors gave final approval of the version to be published. LP agreed to be accountable for all aspects of the work in ensuring that questions related to the accuracy or integrity of any part of the work are appropriately investigated and resolved.

\section{Authors' information}

Current affiliation of Omri Snir is Department of Immunology, Centre for Immune Regulation, Oslo University Hospital-Rikshospitalet, University of Oslo, Oslo, Norway. Current affiliation of Katharina Ute Klich is Department of Cell and Developmental Biology, Max Planck Institute for Molecular Biomedicine, Münster, Germany. Current affiliation of Bo Ding is Observational Research Center, AstraZeneca, Mölndal, Sweden.

\section{Acknowledgements}

We wish to acknowledge financial support from EU-funded projects BTCure and Masterswitch, and support from the Swedish innovation agency Vinnova (COMBINE project). LP was also supported by The Swedish Research Council (Vetenskapsrådet) and King Gustaf V 80-year fund. DGC participation was supported by the Bioinformatic Infrastructure for Life Sciences (BILS). Work in the Spanish group was supported by grant PI11/01048 of the Instituto de Salud Carlos III (Spain) that is partially financed by the European Regional Development Fund of the EU. The funders had no role in study design, data collection and analysis, decision to publish, or preparation of the manuscript.

\section{Author details}

${ }^{1}$ Rheumatology Unit, Department of Medicine at Karolinska University Hospital, Karolinska Institute, Solna, CMM L8:04 Karolinska Hospital, Stockholm SE-171 76, Sweden. ${ }^{2}$ Computational Medicine Unit, Department of Medicine at Karolinska University Hospital, Karolinska Institute, Solna, CMM L8:O5 Karolinska Hospital, Stockholm SE-171 76, Sweden. ${ }^{3}$ Laboratorio de Investigacion 10, Instituto de Investigacion Sanitaria-Hospital Clinico Universitario de Santiago, Travesia de Choupana sn, Santiago de Compostela ES-157 06, Spain. ${ }^{4}$ Institute of Environmental Medicine, Karolinska Institutet, Nobels väg 13, Stockholm SE-171 77, Sweden. ${ }^{5}$ Division of Medical Inflammation Research, Department of Medical Biochemistry and Biophysics, Karolinska Institutet, Scheeles väg 2, B2, Stockholm SE-171 77, Sweden.

Received: 7 February 2014 Accepted: 28 July 2014

Published: 20 August 2014

\section{References}

1. Gibson G: Decanalization and the origin of complex disease. Nat Rev Genet 2009, 10:134-140.

2. Aujla SJ, Ross KR, Chmiel JF, Holguin F: Airway molecular phenotypes in pediatric asthma. Curr Opin Allergy Clin Immunol 2011, 11:122-126.

3. Grunewald J, Idali F, Kockum I, Seddighzadeh M, Nisell M, Eklund A, Padyukov L: Major histocompatibility complex class II transactivator gene polymorphism: associations with Lofgren's syndrome. Tissue Antigens 2010, 76:96-101.

4. Abdel-Nasser AM, Rasker JJ, Valkenburg HA: Epidemiological and clinical aspects relating to the variability of rheumatoid arthritis. Semin Arthritis Rheum 1997, 27:123-140. 
5. Neovius M, Simard JF, Askling J: Nationwide prevalence of rheumatoid arthritis and penetration of disease-modifying drugs in Sweden. Ann Rheum Dis 2011, 70:624-629.

6. van Vollenhoven RF: Treatment of rheumatoid arthritis: state of the art 2009. Nat Rev Rheumatol 2009, 5:531-541.

7. Klareskog L, Ronnelid J, Lundberg K, Padyukov L, Alfredsson L: Immunity to citrullinated proteins in rheumatoid arthritis. Annu Rev Immunol 2008, 26:651-675.

8. Gregersen PK, Silver J, Winchester RJ: The shared epitope hypothesis. An approach to understanding the molecular genetics of susceptibility to rheumatoid arthritis. Arthritis and rheumatism 1987, 30:1205-1213.

9. Klareskog L, Stolt P, Lundberg K, Kallberg H, Bengtsson C, Grunewald J, Ronnelid J, Harris HE, Ulfgren AK, Rantapaa-Dahlqvist S, Eklund A, Padyukov $L$, Alfredsson $L$ : A new model for an etiology of rheumatoid arthritis: smoking may trigger HLA-DR (shared epitope)-restricted immune reactions to autoantigens modified by citrullination. Arthritis and rheumatism 2006, 54:38-46.

10. Huizinga TW, Amos Cl, van der Helm-van Mil AH, Chen W, van Gaalen FA, Jawaheer D, Schreuder GM, Wener M, Breedveld FC, Ahmad N, Lum RF, de Vries RR, Gregersen PK, Toes RE, Criswell LA: Refining the complex rheumatoid arthritis phenotype based on specificity of the HLA-DRB1 shared epitope for antibodies to citrullinated proteins. Arthritis and rheumatism 2005, 52:3433-3438.

11. Snir O, Widhe M, Hermansson M, von Spee C, Lindberg J, Hensen S, Lundberg K, Engstrom A, Venables PJ, Toes RE, Holmdahl R, Klareskog L, Malmstrom V: Antibodies to several citrullinated antigens are enriched in the joints of rheumatoid arthritis patients. Arthritis and rheumatism 2010, 62:44-52.

12. Snir $\mathrm{O}$, Widhe $M$, von Spee $C$, Lindberg J, Padyukov L, Lundberg $K$, Engstrom A, Venables PJ, Lundeberg J, Holmdahl R, Klareskog L, Malmstrom $\checkmark$ : Multiple antibody reactivities to citrullinated antigens in sera from patients with rheumatoid arthritis: association with HLA-DRB1 alleles. Ann Rheum Dis 2009, 68:736-743.

13. Raychaudhuri S, Sandor C, Stahl EA, Freudenberg J, Lee HS, Jia X, Alfredsson L, Padyukov L, Klareskog L, Worthington J, Siminovitch KA, Bae SC, Plenge RM, Gregersen PK, de Bakker PI: Five amino acids in three HLA proteins explain most of the association between MHC and seropositive rheumatoid arthritis. Nat Genet 2012, 44:291-296.

14. van der Helm-van Mil AH, Verpoort KN, Breedveld FC, Huizinga TW, Toes RE, de Vries RR: The HLA-DRB1 shared epitope alleles are primarily a risk factor for anti-cyclic citrullinated peptide antibodies and are not an independent risk factor for development of rheumatoid arthritis. Arthritis and Rheum 2006, 54:1117-1121.

15. Burkhardt H, Sehnert B, Bockermann R, Engstrom A, Kalden JR, Holmdahl R: Humoral immune response to citrullinated collagen type II determinants in early rheumatoid arthritis. Eur J Immunol 2005, 35:1643-1652.

16. Verpoort KN, Cheung $\mathrm{K}$, loan-Facsinay A, van der Helm-van Mil AH, de Vries-Bouwstra JK, Allaart CF, Drijfhout JW, de Vries RR, Breedveld FC, Huizinga TW, Pruijn GJ, Toes RE: Fine specificity of the anti-citrullinated protein antibody response is influenced by the shared epitope alleles. Arthritis Rheum 2007, 56:3949-3952.

17. Mahdi H, Fisher BA, Kallberg H, Plant D, Malmstrom V, Ronnelid J, Charles P, Ding B, Alfredsson L, Padyukov L, Symmons DP, Venables PJ, Klareskog L, Lundberg K: Specific interaction between genotype, smoking and autoimmunity to citrullinated alpha-enolase in the etiology of rheumatoid arthritis. Nat Genet 2009, 41:1319-1324.

18. van der Woude D, Alemayehu WG, Verduijn W, de Vries RR, HouwingDuistermaat JJ, Huizinga TW, Toes RE: Gene-environment interaction influences the reactivity of autoantibodies to citrullinated antigens in rheumatoid arthritis. Nat Genet 2010, 42:814-816. Author reply: 816.

19. Lundberg K, Bengtsson C, Kharlamova N, Reed E, Jiang X, Kallberg H, Pollak-Dorocic I, Israelsson L, Kessel C, Padyukov L, Holmdahl R, Alfredsson L, Klareskog L: Genetic and environmental determinants for disease risk in subsets of rheumatoid arthritis defined by the anticitrullinated protein/ peptide antibody fine specificity profile. Ann Rheum Dis 2012, 72:652-658.

20. Kastbom A, Strandberg G, Lindroos A, Skogh T: Anti-CCP antibody test predicts the disease course during 3 years in early rheumatoid arthritis (the Swedish TIRA project). Ann Rheum Dis 2004, 63:1085-1089.

21. Ronnelid J, Wick MC, Lampa J, Lindblad S, Nordmark B, Klareskog L, van Vollenhoven RF: Longitudinal analysis of citrullinated protein/peptide antibodies (anti-CP) during 5 year follow up in early rheumatoid arthritis:
anti-CP status predicts worse disease activity and greater radiological progression. Ann Rheum Dis 2005, 64:1744-1749.

22. Stolt $P$, Bengtsson C, Nordmark B, Lindblad S, Lundberg I, Klareskog L, Alfredsson $L$ : Quantification of the influence of cigarette smoking on rheumatoid arthritis: results from a population based case-control study, using incident cases. Ann Rheum Dis 2003, 62:835-841.

23. Arnett FC, Edworthy SM, Bloch DA, McShane DJ, Fries JF, Cooper NS, Healey LA, Kaplan SR, Liang MH, Luthra HS, Medsger TA, Mitchell DM, Neustadt DH, Pinals RS, Schaller JG, Sharp JT, Wilder RL, Hunder GG: The American Rheumatism Association 1987 revised criteria for the classification of rheumatoid arthritis. Arthritis Rheum 1988, 31:315-324

24. Montes A, Dieguez-Gonzalez R, Perez-Pampin E, Calaza M, Mera-Varela A, Gomez-Reino JJ, Gonzalez A: Particular association of clinical and genetic features with autoimmunity to citrullinated alpha-enolase in rheumatoid arthritis. Arthritis Rheum 2011, 63:654-661.

25. Aldener-Cannava A, Olerup O: HLA-DPA1 typing by PCR amplification with sequence-specific primers (PCR-SSP) and distribution of DPA1 alleles in Caucasian, African and Oriental populations. Tissue antigens 1996, 48:153-160.

26. Olerup O, Zetterquist H: HLA-DR typing by PCR amplification with sequence-specific primers (PCR-SSP) in 2 hours: an alternative to serological DR typing in clinical practice including donor-recipient matching in cadaveric transplantation. Tissue antigens 1992, 39:225-235.

27. Lundstrom E, Kallberg H, Alfredsson L, Klareskog L, Padyukov L: Geneenvironment interaction between the DRB1 shared epitope and smoking in the risk of anti-citrullinated protein antibody-positive rheumatoid arthritis: all alleles are important. Arthritis Rheum 2009, 60:1597-1603.

28. Lundstrom E, Kallberg H, Smolnikova M, Ding B, Ronnelid J, Alfredsson L, Klareskog L, Padyukov L: Opposing effects of HLA-DRB1*13 alleles on the risk of developing anti-citrullinated protein antibody-positive and anti-citrullinated protein antibody-negative rheumatoid arthritis. Arthritis Rheum 2009, 60:924-930.

29. Padyukov L, Seielstad M, Ong RT, Ding B, Ronnelid J, Seddighzadeh M, Alfredsson L, Klareskog L: A genome-wide association study suggests contrasting associations in ACPA-positive versus ACPA-negative rheumatoid arthritis. Ann Rheum Dis 2011, 70:259-265.

30. Ding B, Padyukov L, Lundstrom E, Seielstad M, Plenge RM, Oksenberg JR, Gregersen PK, Alfredsson L, Klareskog L: Different patterns of associations with anti-citrullinated protein antibody-positive and anti-citrullinated protein antibody-negative rheumatoid arthritis in the extended major histocompatibility complex region. Arthritis Rheum 2009, 60:30-38.

31. Armitage P, Berry G, Matthews JNS: Statistical methods in medical research. 4th edition. Malden, MA: Blackwell Science; 2001

32. Viechtbauer $\mathrm{W}$ : Conducting meta-analyses in $\mathrm{R}$ with the metafor package. J Stat Softw 2010, 36:1-48.

33. Klareskog L, Padyukov L, Alfredsson L: Smoking as a trigger for inflammatory rheumatic diseases. Curr Opin Rheumatol 2007, 19:49-54.

34. van der Woude D, Lie BA, Lundstrom E, Balsa A, Feitsma AL, HouwingDuistermaat JJ, Verduijn W, Nordang GB, Alfredsson L, Klareskog L, Pascual-Salcedo D, Gonzalez-Gay MA, Lopez-Nevot MA, Valero F, Roep BO, Huizinga TW, Kvien TK, Martin J, Padyukov L, de Vries RR, Toes RE: Protection against anti-citrullinated protein antibody-positive rheumatoid arthritis is predominantly associated with HLA-DRB ${ }^{*} 1301$ : a meta-analysis of HLA-DRB1 associations with anti-citrullinated protein antibody-positive and anti-citrullinated protein antibody-negative rheumatoid arthritis in four European populations. Arthritis Rheum 2010, 62:1236-1245.

35. Feitsma AL, van der Voort El, Franken KL, el Bannoudi H, Elferink BG, Drijfhout JW, Huizinga TW, de Vries RR, Toes RE, loan-Facsinay A: Identification of citrullinated vimentin peptides as T cell epitopes in HLA-DR4-positive patients with rheumatoid arthritis. Arthritis Rheum 2010, 62:117-125.

36. Snir O, Rieck M, Gebe JA, Yue BB, Rawlings CA, Nepom G, Malmström V, JH $B$ : Identification and functional characterization of $T$ cells reactive to citrullinated-vimentin in HLA-DRB1*0401 humanized mice and RA patients. Arthritis Rheum 2011, 63:2873-2883.

37. James E, Rieck M, Pieper J, Gebe JA, Yue BB, Tatum M, Peda M, Sandin C Klareskog L, Malmstrom V, Buckner JH: Citrulline specific Th1 cells are increased in rheumatoid arthritis and their frequency is influenced by disease duration and therapy. Arthritis Rheum 2014, 66:1712-1722.

38. Scally SW, Petersen J, Law SC, Dudek NL, Nel HJ, Loh KL, Wijeyewickrema LC, Eckle SB, van Heemst J, Pike RN, McCluskey J, Toes RE, La Gruta NL, Purcell AW, Reid HH, Thomas R, Rossjohn J: A molecular basis for the 
association of the HLA-DRB1 locus, citrullination, and rheumatoid arthritis. J Exp Med 2013, 210:2569-2582.

39. Begovich AB, Carlton VE, Honigberg LA, Schrodi SJ, Chokkalingam AP, Alexander HC, Ardlie KG, Huang Q, Smith AM, Spoerke JM, Conn MT, Chang M, Chang SY, Saiki RK, Catanese JJ, Leong DU, Garcia VE, McAllister LB, Jeffery DA, Lee AT, Batliwalla F, Remmers E, Criswell LA, Seldin MF, Kastner $\mathrm{DL}$, Amos Cl, Sninsky JJ, Gregersen PK: A missense single-nucleotide polymorphism in a gene encoding a protein tyrosine phosphatase (PTPN22) is associated with rheumatoid arthritis. Am J Hum Genet 2004, 75:330-337.

40. Zikherman J, Hermiston M, Steiner D, Hasegawa K, Chan A, Weiss A: PTPN22 deficiency cooperates with the CD45 E613R allele to break tolerance on a non-autoimmune background. J Immunol 2009, 182:4093-4106.

41. Menard L, Saadoun D, Isnardi I, Ng YS, Meyers G, Massad C, Price C, Abraham C, Motaghedi R, Buckner JH, Gregersen PK, Meffre E: The PTPN22 allele encoding an R620W variant interferes with the removal of developing autoreactive B cells in humans. J Clin Invest 2011, 121:3635-3644.

42. Raychaudhuri S, Remmers EF, Lee AT, Hackett R, Guiducci C, Burtt NP, Gianniny L, Korman BD, Padyukov L, Kurreeman FA, Chang M, Catanese JJ, Ding B, Wong S, van der Helm-van Mil AH, Neale BM, Coblyn J, Cui J, Tak PP, Wolbink GJ, Crusius JB, van der Horst-Bruinsma IE, Criswell LA, Amos Cl, Seldin MF, Kastner DL, Ardlie KG, Alfredsson L, Costenbader KH, Altshuler D, et al: Common variants at CD40 and other loci confer risk of rheumatoid arthritis. Nat Genet 2008, 40:1216-1223.

43. van der Linden MP, Feitsma AL, le Cessie S, Kern M, Olsson LM, Raychaudhuri S, Begovich AB, Chang M, Catanese JJ, Kurreeman FA, van Nies J, van der Heijde DM, Gregersen PK, Huizinga TW, Toes RE, van der Helm-Van Mil AH: Association of a single-nucleotide polymorphism in CD40 with the rate of joint destruction in rheumatoid arthritis. Arthritis Rheum 2009, 60:2242-2247.

44. Weedon MN, Lango H, Lindgren CM, Wallace C, Evans DM, Mangino M, Freathy RM, Perry JR, Stevens S, Hall AS, Samani NJ, Shields B, Prokopenko I, Farrall M, Dominiczak A, Diabetes Genetics I, Wellcome Trust Case Control C, Johnson T, Bergmann S, Beckmann JS, Vollenweider P, Waterworth DM, Mooser V, Palmer CN, Morris AD, Ouwehand WH, Cambridge GEMC, Zhao $J$ H, Li S, Loos RJ, et al: Genome-wide association analysis identifies 20 loci that influence adult height. Nat Genet 2008, 40:575-583.

45. Okada Y, Hirota T, Kamatani Y, Takahashi A, Ohmiya H, Kumasaka N, Higasa K, Yamaguchi-Kabata Y, Hosono N, Nalls MA, Chen MH, van Rooij FJ, Smith AV, Tanaka T, Couper DJ, Zakai NA, Ferrucci L, Longo DL, Hernandez DG, Witteman JC, Harris TB, O'Donnell CJ, Ganesh SK, Matsuda K, Tsunoda T, Tanaka T, Kubo M, Nakamura Y, Tamari M, Yamamoto K, et al: Identification of nine novel loci associated with white blood cell subtypes in a Japanese population. PLoS Genet 2011, 7:e1002067.

46. Reiner AP, Lettre G, Nalls MA, Ganesh SK, Mathias R, Austin MA, Dean E, Arepalli S, Britton A, Chen Z, Couper D, Curb JD, Eaton CB, Fornage M, Grant SF, Harris TB, Hernandez D, Kamatini N, Keating BJ, Kubo M, LaCroix A, Lange LA, Liu S, Lohman K, Meng Y, Mohler ER 3rd, Musani S, Nakamura Y, O'Donnell CJ, Okada Y, et al: Genome-wide association study of white blood cell count in 16,388 African Americans: the continental origins and genetic epidemiology network (COGENT). PLoS Genet 2011, 7:e1002108.

47. Wang Y, Wysocka J, Sayegh J, Lee YH, Perlin JR, Leonelli L, Sonbuchner LS, McDonald CH, Cook RG, Dou Y, Roeder RG, Clarke S, Stallcup MR, Allis CD, Coonrod SA: Human PAD4 regulates histone arginine methylation levels via demethylimination. Science 2004, 306:279-283.

48. Suzuki A, Yamada R, Chang X, Tokuhiro S, Sawada T, Suzuki M, Nagasaki M, Nakayama-Hamada M, Kawaida R, Ono M, Ohtsuki M, Furukawa H, Yoshino S, Yukioka M, Tohma S, Matsubara T, Wakitani S, Teshima R, Nishioka Y, Sekine A lida A, Takahashi A, Tsunoda T, Nakamura Y, Yamamoto K: Functional haplotypes of PADI4, encoding citrullinating enzyme peptidylarginine deiminase 4, are associated with rheumatoid arthritis. Nat Genet 2003, 34:395-402.

49. Eyre S, Bowes J, Diogo D, Lee A, Barton A, Martin P, Zhernakova A, Stahl E, Viatte S, McAllister K, Amos Cl, Padyukov L, Toes RE, Huizinga TW, Wijmenga C, Trynka G, Franke L, Westra HJ, Alfredsson L, Hu X, Sandor C, de Bakker PI, Davila S, Khor CC, Heng KK, Andrews R, Edkins S, Hunt SE, Langford C, Symmons D, et al: High-density genetic mapping identifies new susceptibility loci for rheumatoid arthritis. Nat Genet 2012, 44:1336-1340.
50. Too CL, Murad S, Dhaliwal JS, Larsson P, Jiang X, Ding B, Alfredsson L, Klareskog $L$, Padyukov L: Polymorphisms in peptidylarginine deiminase associate with rheumatoid arthritis in diverse Asian populations: evidence from MyEIRA study and meta-analysis. Arthritis Res Ther 2012 14:R250.

51. Park $C$, Jeong NY, Kim GY, Han MH, Chung IM, Kim WJ, Yoo YH, Choi YH: Momilactone B induces apoptosis and G1 arrest of the cell cycle in human monocytic leukemia U937 cells through downregulation of pRB phosphorylation and induction of the cyclin-dependent kinase inhibitor p21Waf1/Cip1. Oncol Rep 2014, 31:1653-1660.

52. Hafler DA: Perspective: Deconstructing a disease. Nature 2012, 484:S6.

doi:10.1186/s13075-014-0414-3

Cite this article as: Snir et al:: Non-HLA genes PTPN22, CDK6 and PADI4 are associated with specific autoantibodies in HLA-defined subgroups of rheumatoid arthritis. Arthritis Research \& Therapy 2014 16:414.

\section{Submit your next manuscript to BioMed Central and take full advantage of:}

- Convenient online submission

- Thorough peer review

- No space constraints or color figure charges

- Immediate publication on acceptance

- Inclusion in PubMed, CAS, Scopus and Google Scholar

- Research which is freely available for redistribution

Submit your manuscript at www.biomedcentral.com/submit
C) Biomed Central 